Вісник ЛНУ імені Тараса Шевченка № 7 (330), 2019

УДК $340.113+81^{\prime} 276.6$

doi : 10.12958/2227-2844-2019-7(330)-30-39

Tsareva I. V.,

$\mathrm{PhD}$, Associate Professor of Social and Humanitarian Sciences Department

of Dnipropetrovsk State University of Internal Affairs,

Dnipro, Ukraine

tsarevasgd@ukr.net

https://orcid.org/0000-0002-1939-7912

\title{
DERIVATIVE SPACE OF THE LAW TEXT
}

Derivative dynamic lexicology sets the synchronous meaning for the concept of "genesis", ,genetic" and it is thought that using of any „finished" word in the language is its production and reproduction at the same time (in one or another correlations). At he same time, the derivative lexicology makes the main emphasis on the creation and always underlines that creations involves the moment of interaction of the linguistic output (previous) and linguistic derivative (further). The widest (and simultaneously deep) determinatory sense of „outgoing” appears as a communicative content, which seeks to be embodied in the corresponding linguistic forms. Identifying components in the structure of derivative word, which can be qualified as theme and rheme or given and new (Сахарный, 1979), is not only geneticallydiachronic fact but also genetically-synchronical fact specifying lexical derivation processes inclusion into text production processes. The necessity of relying on the given (the initial) when lexical items are chosen (formed) arises in the process of speech production, much as when speaker relies on his previous text fragments to form new fragments (Мурзин, 1974) while formating the text.

Thus primary task of motivational component of unlimited derivational lexis functioning is suppositional provision of regular processes of lexical units derivation (newly created or new ones). This function is derived from the necessity to base on previous (given, old, known) units while creating the new (in broad sense of this term). These units act as suppositions in relation to the first ones. Suppositional function in initial links of determinational chain is communicative by nature as it results from the speaker's need to be understood by the addressee due to the fact that the speaker „prefers” to rely on what has already been known to his addressees. Motivational elements in derivative embody syntactical deductivity from initial communicative base and derivative functioning and development of the latter: mental disability as well as mental capacity is a legal notion; a minor crime should be distinguished from a wrongdoing without the elements of crime (Голев, 1998, c. 13-33).

The components of unit novelty distinguishing it from initial unit represent the derivational component of this process. The elements (units, 
rules, norms) of lexical derivation-motivation for a long time have been forming by necessity of the language derivation of words and are relatively independent, complete systematic-functional unit in language. They closely interact with the units and rules of other levels, absorb their functions and peculiarities, at the same time they are quite independent and for that reason conventional towards them formation.

Capability of words and word forms to transform into motivational bases (namely they are morphemes) of created words when creating suppositional function is the example of such interaction in structural sense: Limited capacity as well as capacity and disability are characterized by two criteria medical (biological) and legal (psychological), combination of which give grounds to declare a person as partially incapacitated: base capacity in some way is the same word as capacity and/or capacitated but in another structuralfunctional status (the Commentary on article 20 of the Criminal Code of Ukraine).

The example of functional and normative plan of lexical derivationmotivation can be pragmatic inequivlence of synonymic changes in lexicalderivative row: drunkenness is the cause of many crimes. That is why the Criminal Code of Ukraine considers drunkenness as aggravating circumstance (the Commentary on the Criminal Code of Ukraine, P. 13, Part 1, Clause 67). In this context words criminally liable, conditions, period, visualization can be semantically possible instead of derivates drunkenness, reaching the age, prediction but it is unlikely that they will safe pragmatics and initial communicative idea of the expressions given above.

Undouptedly, such normativity is dubious. It is realized in combination with normativity of lexical type. Overcoming conventionality (if it as actualized in language) is accompanied with specific connotations which shows the formation of lexical-semantic norms. Such actualization indicates innovations, violation of norms; relieving of conventionality is perceived as semantic derivation act. Double functioning of motivationa base: A mistake as to criminality of action means that a person considers their activity (inactivity) as a crime, though the Criminal Code of Ukraine does not define it as a crime (simulated crime).

The example shows the identification of motivation base with motivation word ignoring conventionality of their correlation, idiomaticity of motivator: penetrating participants of that kind of unions into public and local authorities to provide «roof» (protection) for criminal activity of organized group or criminal organization; quotation marks testify to actualization of idiomatic increment in «dictionary» motivator safety, perception the moment of norm violation (= nonidentity of morph roof- and „free” motivator safety).

Functional-dynamic side of the inner word form is determined by its involvement into continuous derivational and motivative process being the core of the whole lexical and derivative dynamics. Opposition of plans for derivates creation and functioning, their encountering with one of the most influentional driving forces of this process and can be taken as the basis for its description. Contradiction of plans mentioned above lies in that fact that the 


\section{Вісник ЛНУ імені Тараса Шевченка № 7 (330), 2019}

word created once in one situation does not always demand compulsive derivational and motivative mechanism at a later stage but the mechanism itself continues permanent acting in the same way in similar situations. The situation in which the word arose (or could arise) repeats naturally that allows repeated acts of its creation.

The Commentary on article 50 of the Criminal Code of Ukraine The definition of punishment and its purpose defines: The punishment is aimed not only at penalizing but also reformation of sentenced persons and prevention of further offenses by both the sentenced and other persons; Penalty of sentenced person is always fulfilled when punishment is used. Derivate penalty is in the focus of creation. Works of famous lawyers and criminalists pay special attention to the concept penalty, in such event concepts penalty and punishment in most of concepts enter into hyper-hyponymic relations: penalty is either purpose or essence of punishment. Lexical units are united by one cetegorial seme as a result of which one notion relates to another but wider in semantic plan and calls more denotats. Asymmetry of hyper-hyponymic relations is put in the structure of hyponymy (subordination) and hyperonymy (domination) (Денисова, 1996). Regular rederivation processes being in continuous derivative-motivational process in one row with direct derivation are not less important.

Emerge of new formation is a private result of word functioning under ordinary conditions of its derivative spreading, so plans of creation and functioning of the word determine each other. The nature of determination is different in different directions: in one case it is genetical (from creating to functioning), in the other it is synchronical-functional (from functioning to creation). There can be a differentiation between perspective (from structural motivator to structural motive) and retrospective (from structural motivator to structural motive) lines of motivational dynamics in progressive direction. Their opposition in language is often neutralized as progressive movement of language thought from the given to the new, universal for text production as though it „perspected” all textual derivative connections: Fact of damage is not important for classification of crime (the Criminal Code of Ukraine, article 11). But actual damage caused by the criminal gives grounds for extra qualification of the crime under another article of the Criminal Code of Ukraine (for example, article 112): one of textual motives is structurally more complicated than motivator for derivational topic development in the given context.

When defining the system one should follow the principle of dialectical unity with the definition of function. The function, on the one hand, originates from systematic location of certain object and, on the other hand, defines location of this object in the system and, as the result defines inner structure of the system as a whole. Within derivational lexicology functional-dynamic and system plans of the word are mutually complementary and presuppose each other: vocabulary enrichment is realized through textual lexical derivation, at the same time, epidigmatic text structure is mostly formed as systematic epidigmatic realization. 


\section{Вісник ЛНУ імені Тараса Шевченка № 7 (330), 2019}

Lexical units derivation is the specific type of source units functioning and development. This is, so to say, the functioning of units that admits of their modification. In contemporary Ukrainian legal text legal terms are interpreted as different nominative units. Simple lexical units convey global view of life (act, liability, action, law, capacity, defence, ground, punishment). Nominative units of legal termsystem, that is, different derivative and complex words and word combinations are equivalent to simple lexical units. Derivative and complex words being terms of jurisprudence most of all convey basic and differential features of extralinguistic reality. Word formations repeat elements of main category but are distinguished by features of addition, stress and are oriented to subcategorization of one category on different grounds which are valuable for speciaists in the sphere of law.

Comprehensive researches of functional orientation of derivative form are the base for regarding derivative system of language as the potential of its language functioning. Derivative word functioning in the text occurs, firstly, in lexical-derivative raw formation (LDR) which stands for sequence of cognate or oneaffixal words (including „clear” repetitions) crossing discretive textual space (context) (Голев, 1989, с. 96), secondly, lexical row, that is, the sequence of words with determination relations where derivative relations do not have formal nature. These rows are part of inner form of the text, connective cores performing its ontological unity in words and morphemes repetitions. Obligatory functioning of lexical-derivative and lexical rows in the text proves the involvement of lexical derivation into the text derivation processes and into continuous derivative and motivative flow as a whole.

The continuity of the derivation-motivational processes in the language is associated with the continuity of the derivation field of the word in the language system. The two most important axes of the derivational variation of the word are formal and semantic variations, which lead to the appearance of two different semantically functional units - the derivation words and specifications that are the basic concepts of derivational lexicology.

The peculiarity of the derivational word as a semantic-functional unit of the lexical-derivative system, as distinct from other aspects of the study of the word within the framework of level grammar, is associated with the actualization of the formal-semantic connections of the word with other words.

The notion of the derivational form of the word is based on the understanding of the identity of the word allowing for the distinctive features in its use. Consequently, it is a tool for distinguishing between discrete individual-unique semantic qualities which contradict the continuity of the general derivation-motivational flow in the semantic language space. On the other hand, it actively performs a suppositive function in the process of creating / reproducing / choosing a lexical unit, specification and maintaining continuity.

The word realizes its potential of derivational functioning in the text, and ,the functional properties of the word in the text are in double contextuality. These properties are determined by the general features of the word as a unit of the lexical system and specified by the properties of the word, which are 


\section{Вісник ЛНУ імені Тараса Шевченка № 7 (330), 2019}

inserted in it in the text itself in a certain system of dependencies", therefore, two aspects of the issues of derivational lexicology study are outlined: lexicocentric, when the word as the carrier of its formalized-semantic potential dominates, and text-centric (syntactic-centric), when the text (context) is studied, which provides conditions for the realization of the functioning word potential.

Hence the orientation either on the properties of the word as a representative of the derivative system of lexis (degrees of division, motivation), or on the properties of the context, which determine certain features of the derivative function of the word, therefore the variation of the context can serve as a way of identifying and studying the potential of its functioning.

If the lexical derivation is included in the syntactic (comp.: „lexical derivation, paradoxically, is the syntactic process, directly related to the formation of a sentence in the text"), then the functional LDR acts as an intermediate link between the unisolated word and the proposition that is the basis of the continuous derivation-motivational process of the text in its lexical view. Lexico-derivative space of the text forms an independent text dimension. If we consider LDR as a „,whole entity”, „,text complex”, ,another minor unit of the text-level language" (Вихованець, 1983), then we give it an intermediate position between the lexical and syntactic levels and we believe that any change in the lower or higher levels leads to the change of LDR. Therefore, the interaction between the text and the derivational word is determined.

The study of a functional derivational word on the background of functional derivational text, in which the word implements its potential for formal semantic development, is of great interest in the field of derivational lexicology. At the same time, it is necessary to review the basic concepts of the theory, because really functional description of the dictionary system is carried out through the interaction of semantics of nominative units with an appropriate syntactic theory. On this basis we can highlight two studying directions of the derivational word in the epistemological term: from the word and from the text, but the problem of the interaction between the functional derivational word and the text has not been set. The need for research is determined by a number of epistemological reasons including ,the separation of lexical derivation from general-text derivation” (Голев, 1989, с. 17-26).

The structures of the phrase that are widely used are the ones one of the components of which is a word with a commonly used neutral meaning особа in combination with the corresponding adjective, which leads to this cluster becoming a term. The texts of the CCU are characterized by complex substantive-adjective three-component constructions with the pivotal wordnoun and dependent adjectives. Among the substantive terminological phrases there are structures connected by the link of management. Thus, the productive pattern consists of the verb noun in nominative case and noun in the genetive case. 
A significant group of substantive phrases consists of prepositional noun constructions such as responsibility for crimes, attempt to crime committing, complicity in a crime, the question of application, evasion of punishment, in which the main component requires the use of the corresponding noun with the preposition, for example: Preparation for a small gravity crime does not entail criminal liability (CCU, R. III (ML), Article 14); An attempt to commit a crime is the commission of a person with a direct intent of an act (action or inaction) (CCU, R. III (ML), Article 15).

These syntactic structures are not considered to be productive in the texts being studied. As you know, the word combination can be regarded as a complex one when it contains optional elements that can be removed from the corresponding structure without its destruction as a syntactic unit of a certain type. It is worth paying attention to the fact that terminological phrases are characterized by their stable fixed structure, which makes impossible to extract these or those components.

It is quite common thing when the basis of the complex term is one or more simple phrases, as in the following sentence: An executor (co-executor) bears criminal responsibility under the article of the Special Part of this Code, which provides for a crime committed by him (CCU, R. VI (ML), Article 29). Multi-task nature of complex terminological phrases should be taken into account during the analysis of the language of the CCU, when they are highlighted in the text. Such phrases are also called combined, as the dependent component in them is also essentially a phrase, for example: Foreigners who have committed crimes in Ukraine and convicted for them on the basis of this Code may be transferred for serving the sentence for the crime committed in the State whose citizens they are, if such a transfer is provided for by international treaties of Ukraine (CCU, RP II (MOU), Article 10).

It is to be noted that the structure of complex terminological units sometimes includes its own names, for example: An attack on the life of the President of Ukraine, the Chairman of the Verkhovna Rada of Ukraine, the people's deputy of Ukraine, the Prime Minister of Ukraine ... is committed in connection with their state or social activities (CCU , P. 1 (OC), Article 12).

The specificity of the language of the modern legislative text is also made up of structures that have a number of terminological phrases. Each specific term has a specific fixed meaning: Preparing for a crime is to seek or adapt means or equipment, search for accomplices or conspiracy to commit a crime, eliminate obstacles, and other deliberate creation of conditions for committing an offense (CCU, RI III (ML), Art. 14). An option of this structure can be a combination of a given model with a noun in the Instrumental case: The repetition provided for in part one of this article is absent in the commission of an ongoing crime consisting of two or more identical acts united by a single criminal intention (CCU, RV (OC), Article 184);

Allocate terminological phrases in which the verbal noun of the violation is used in the form of singular and combined with the noun in Genitive Case: Violation of the secrecy of voting (CCU, RV (OC). Terminological phrases of 
a more complicated structural organization, allow you to convey the content of the legal norm more precisely, to cover certain details, for example: Violation of the right to free medical care (CCU, RV (OC), Article 184).

Consequently, the modern Ukrainian legal text is actively replenished with two- and multi-component terminology units to designate new concepts or to improve or refine already existing ones. Composed legal terms are syntactic constructions, consisting of two or more notional words based on subordinate connection. It was found out that only a few polycomponent termnouns can be combined by means of ordinate connection. Formation of multicomponent terms, their transition from simple to verbose units occurs in stages and, accordingly, is accompanied by reformation and complication of the syntactic model. Consequently, the word combinations can be referred to terminological ones when their components are assumed as a single notion and have a clearly formulated and fixed meaning. To solve the problem of the word and the text interaction, we involve translingual space as the only speech-language matter in its derivational aspect, revealing the peculiarities of the word functioning in the context of derivational textology obtained when comparing texts that are in the relations of derivability. Under the derivative potential of the text we understand the ability of the text to enter the derivational relations with other texts. In this case, the lexical-derivative development of the text acts as one of the manifestations of the continuous derivational and motivational process.

\section{Список використаної літератури}

1. Сахарный Л. В. Психолингвистические аспекты теории словообразования. Л., 1985. 97 с. 2. Мурзин Л. Н. Синтаксическая деривация. Пермь, 1974. З. Голев Н. Д. К основаниям деривационной лексикологии русского языка: лексико-деривационные контексты как форма проявления деривационной энергетики текста и слова в тексте (проблемы, задачи, перспективы). Очерки по лингвистической детерминологии и дериватологии русского языка. Барнаул, 1998. С. 1333. 4. Денисова С. П. Типологія категорій лексичної семантики. К.: Видво Київського держ. лінгвістичного ун-ту, 1996. 294 с. 5. Голев Н. Д. Динамический аспект лексической мотивации. Томск, 1989.252 с. 6. Вихованець I., Городенська К., Русанівський В. Семантикосинтаксична структура речення. Київ: Наук. думка, 1983. С. 143.

\section{References \\ 1. Saharnyj, L.V. (1985). Psiholingvisticheskie aspekty teorii} slovoobrazovaniya [Psycholinguistic aspects of word formation theory]. Leningrad [in Russian]. 2. Murzin, L. N. (1974). Sintaksicheskaya derivaciya [Syntactic derivation]. Perm' [in Russian]. 3. Golev, N. D. (1998). K osnovaniyam derivacionnoj leksikologii russkogo yazyka: leksikoderivacionnye konteksty kak forma proyavleniya derivacionnoj energetiki teksta i slova $v$ tekste (problemy, zadachi, perspektivy) [To the foundations of derivational lexicology of the Russian language: lexico-derivational contexts 
as a form of manifestation of derivational energetics of a text and a word in a text (problems, tasks, prospects)]. Ocherki po lingvisticheskoj determinologii $i$ derivatologii russkogo yazyka - Essays on Linguistic Determinology and Derivatology of the Russian Language. Barnaul (pp. 13-33) [in Russian]. 4. Denysova, S. P. (1996). Typolohiia katehorii leksychnoi semantyky [Typology of the category of lexical semantics]. Kiev [in Ukrainian]. 5. Golev, N. D. (1989). Dinamicheskij aspekt leksicheskoj motivacii [Dynamic aspect of lexical motivation]. Tomsk [in Russian]. 6. Vykhovanets, I., Horodenska K. \& Rusanivskyi V. (1983). Semantykosyntaksychna struktura rechennia [The semantic-syntactic structure of the speech]. Kyiv: Nauk. dumka (p. 143) [in Ukrainian].

\section{Царьова І. В. Дериваційний простір юридичного тексту}

Стаття присвячена вивченню створення дериваційного простору слова в сучасному українському юридичному тексті. Дослідження здійснено в руслі сформованої концепції дериваційної лексикології. Теоретична частина пропонованого доробку окреслює те підгрунтя, що лежить в основі деривації. Убачаємо відмінність форм слова не тільки в різновидах морфологічної структури, а й в розмаїтті так званих лексичних форм, які складають модель дериваційного слова: 1) синтетичні i аналітичні форми словозміни; 2) фономорфологічні варіанти слова; 3) етимологічні варіанти слова; 4) лексико-стилістичні варіанти слова; 5) лексико-синтаксичні варіанти слова; 6) лексикофразеологічні варіанти. Зазначено, що різні види дериваційних зв'язків, ïх неоднолінійність і нерівномірність визначають основні особливості моделі. Зображено динамічний характер дериваційного розвитку слова, що забезпечується двома способами, які полягають в утворенні дериваційних слів і специфікацій. Описано уявлення про моделі дериваційного простору слова: представлених форм i зв'язків дериваційного функціонування, які розглядаються нами як складники дериваційного потенціалу, під яким розуміється готовність слова творити (перспективне функціонування) i бути твірним (ретроспективне функціонування). На прикладі дериваційного функціонування юридичної лексики зовнішня детермінаційність трактується як ефект самодетермінації лексичної системи. Юридичним текстам, залежно від функціональної мети, притаманна певна організація, принципи й правила виконання, стиль написання тощо. Доведено, що в дериваційного простору слова є глибинний складник, представлений парадигматичними зв'язками однокореневих слів.

Ключові слова: деривація, модель дериваційного простору, лексикодериваційні зв’язки, семема, юридичний текст. 
Вісник ЛНУ імені Тараса Шевченка № 7 (330), 2019

\section{Царёва И. В. Деривационное пространство юридического текста}

Статья посвящена изучению создания деривационного пространства слова в современном украинском юридическом тексте. Исследование осуществлено в русле сложившейся концепции деривационной лексикологии. Теоретическая часть предлагаемого доработку определяет то основание, что лежит в основе деривации. Усматриваем различие форм слова не только в разновидностях морфологической структуры, но и в разнообразии так называемых лексических форм, которые составляют модель деривационного слова: 1) синтетические и аналитические формы словоизменения; 2) фономорфологични варианты слова; 3) этимологические варианты слова; 4) лексико-стилистические варианты слова; 5) лексикосинтаксические варианты слова; 6) лексико-фразеологические варианты. Отмечено, что различные виды деривационных связей, их неоднолинийнисть и неравномерность определяют основные особенности модели. Изображен динамичный характер деривационного развития слова, обеспечивается двумя способами, которые заключаются в образовании деривационных слов и спецификаций. Описаны представление о модели деривационного пространства слова: представленных форм и связей деривационного функционирования, которые рассматриваются нами как составляющие деривационного потенциала, под которым понимается готовность слова творить (перспективное функционирования) и быть образующим (ретроспективное функционирования). Юридическим текстам, в зависимости от функциональной цели, присуща определенная организация, принципы и правила выполнения, стиль написания и т.д. Доказано, что в деривационного пространства слова есть глубинный составляющая, представленный парадигматическими связями однокоренных слов.

Ключевые слова: деривация, модель деривационного пространства, лексико-деривационные связи, семема, юридический текст.

\section{Tsareva I. V. The derivative space of the law text}

The article is devoted to the study of derivative word space in modern Ukrainian law text. The research is carried out in line with the developed concept of derivative lexicology. The theoretical part of the proposed refinement outlines the basis underlying the derivation. We see the difference between word forms not only in varieties of morphological structure, but also in the variety of so-called lexical forms that make up the model of the derivative word: 1) synthetic and analytical forms of word change; 2) phonomorphological variants of the word; 3) etymological variants of the word; 4) vocabulary and stylistic variants of the word; 5) vocabulary and syntactic variants of the word; 6) lexico-phraseological variants. It is noted that different types of derivative bonds, their non-uniformity and non- 
uniformity determine the main features of the model. The dynamic character of derivative word development is provided, which is provided in two ways, which are the formation of derivative words and specifications. Descriptions of derivative word space models are presented: presented forms and relations of derivative functioning, which we consider as components of derivative potential, by which we mean the readiness of the word to create (perspective functioning) and to be creative (retrospective functioning). It is proved that the derivative space of a word has a deep component represented by paradigmatic connections of single-root words. The derivativeness of the modern Ukrainian legal text is considered as a sphere of the functional-derivative space of the legal language. Versatility and multilevel of the organization of legal text testifies that him it is difficult to inlay in the usual linear scopes of that linguistic science that was formed on the exposure of certain corps of units and their further classification.

Key words: derivation, derivative space model, lexical derivative relations, semes, law text.

Стаття надійшла до редакції 15.10.2019 р.

Стаття прийнята до друку 22.10.2019 р.

Рецензент - д. філол. н., проф. Білоусенко П. І. 